\title{
Towards a Right to Digital Justice? The Constitutionalization of Digital Justice in Mexico
}

Mauro Arturo Rivera León <arturo.riverale@gmail.com>

Rodrigo E. Galán Martínez<rodrigo.galanmtz1@gmail.com> MEXICO CITY, Mexico

\section{Abstract}

Mexico introduced elements of digital justice in the 2013 Amparo Act. The 2020 COVID pandemic forced a full transition to digital justice to address the forced suspension of activities. However, the lack of a full normative framework and the disparity between the Federal and State Judicial Powers present strong challenges to digitalization. In 2020, the Mexican Senate approved an amendment to constitutionalize digital justice. Even though a constitutional right to digital justice would be a pioneer innovation, the authors conclude that many challenges lie ahead.

\section{Introduction}

Law is a predominantly conservative discipline. It is often said that normative provisions tend to "chase" social reality and societal change rather than fostering them. The usage of new technologies in judicial proceedings has not been the exception. Digital justice has been an increasing challenge in the world, especially in the last fifteen years. Many countries have developed mechanisms adjusted to their adaptation pace and technological possibilities, in a constant struggle between evolution and resistance to change.

The 2020 outbreak of the COVID-19 Pandemic turned out to be a tough test on the world's capacity to perform remote working, distant activities, and the transition into the digital sphere. Given the risks associated with physical activities, digital justice was suddenly not only seen as "desirable" but as "necessary."

This article will analyze Mexico's evolution from the struggle to provide digital justice to the likelihood of establishing a constitutional right to digital justice. Section II) will analyze the 2020 full transition to online 
procedures, accelerated by the COVID-19 Pandemic. We will present the argument that as of the 2013 Amparo Act, Mexico has advanced notably in the possibility of providing digital procedures, notwithstanding restricted to a single type of case. It will be shown that the Federal Judiciary relied on such legal framework and experience to extend online procedures in 2020-2021 as a response to the issues associated with the forced suspension of activities. Section III) will analyze the explanatory memoranda, content, and feasibility of the recent constitutional amendment approved by the Mexican Senate to institutionalize a constitutional right to digital justice. In section IV), we set the challenges ahead, concluding that even after the amendment's potential approval, a constitutional right to digital justice will require more than normative provisions.

\section{A Forced Transition: Online Justice at the Federal Level}

a) Constitutional justice and digital justice: the pre-pandemic beginning. Mexico possesses a mixed constitutional justice system ${ }^{1}$ with elements of both the diffuse and concentrated constitutional control models. At the federal level, the constitutional control procedures are the Amparo trial ${ }^{2}$, actions of unconstitutionality, constitutional controversies, and a peculiar procedure, introduced by the 2011 constitutional amendment, the so called "general declaration of unconstitutionality".

As of 2013, Mexican constitutional justice has implemented elements of digital justice. The 2013 Amparo Act established the possibility of electronically filing Amparo suits. The Amparo Act regulated creating a digital system through which documentation could be filed employing an electronic signature ${ }^{3}$.

1 Prior to 2011, only the Supreme Court and Federal Judges were permitted to perform constitutional control (mostly through Amparo). However, the Supreme Court changed its doctrine in the ruling "Varios 912/2010" affirming the ability of every judge to perform a diffuse constitutional control.

2 Amparo is a procedure pertaining to the defense of human rights with universal legal standing. The Supreme Court, Circuit Courts, Unitary Courts and District Courts are all competent to solve Amparo in a complex system of competence distribution. For the Supreme Court perspective see Arturo Zaldívar, Hacia una Nueva Ley de Amparo ( $1^{\text {st }}$ ed. IIJ-UNAM 2002) 122.

3 This was considered a great innovation by the Amparo Act. See Rosa González, 'Sobre la competencia' in Guadalupe Tafoya (ed), Elementos para el estudio del Juicio de Amparo (Suprema Corte de Justicia de la Nación 2017) 191. 
The Supreme Court and the Federal Council of the Judiciary further developed the normative provisions by creating FIREL (the Federal Judiciary's electronic signature). FIREL is the digital instrument replacing the autograph signature, enabling access to digital case files, and additionally permission to serve documents and receive official notifications ${ }^{4}$, inter alia. In the case of judges/judicial clerks, it allows them to sign official resolutions electronically and to create an electronic case file for each case. ${ }^{5}$

A FIREL may be obtained through an electronic request to the Federal Council of the Judiciary, by attaching a digitalized form of the applicant's identification. Subsequently, the Federal Council of the Judiciary will grant the applicant an official administrative appointment to review the original documentation and record their biometric data. If the validation is successful, the procedure concludes by issuing the digital electronic signature sent by an authorized e-mail to the applicant ${ }^{6}$. As the digital filing of documents is non-compulsory for the parties, the option of filing documents either physically or digitally (or through both modalities) has been upheld.

Electronic case files are also extensively regulated. Digital records of every case file are produced by the digitally filed documents and physically filed documents (which Courts are under obligation to scan). Parties are also entitled to request the official serving of documents within the digital system. ${ }^{7}$

Electronic files pertaining to the Supreme Court developed in slower motion. All parties were expressly allowed to access the Supreme Court's electronic files relating to Amparo trials only until 2015, under the stipulation that an authorized request was provided ${ }^{8}$. In fact, initiating access to interlocutory decisions or judgments through the electronic files by any party automatically performs an official serving of the notice of entry by

4 Adriana Campuzano, Manual para entender el Juicio de Amparo ( $1^{\text {st }}$ edn Thomson Reuters 2016) 67.

5 See “Acuerdo General Conjunto número 1/2013 de la Suprema Corte de Justicia de la Nación, del Tribunal Electoral del Poder Judicial de la Federación y del Consejo de la Judicatura Federal, relativo a la Firma Electrónica Certificada del Poder Judicial de la Federación (FIREL) y el expediente electrónico”.

6 ibid.

7 ibid.

8 See "Acuerdo General Conjunto de la Suprema Corte de Justicia de la Nación, del Tribunal Electoral del Poder Judicial de la Federación y del Consejo de la Judicatura Federal, que regula los servicios tecnológicos relativos a la tramitación electrónica del juicio de amparo, las comunicaciones oficiales y los procesos de oralidad penal en los Centros de Justicia Penal Federal”. 
generating a digital record of such access, thus putting the wheels of any appeal or legal action into motion'.

Therefore, the 2013 Amparo Act laid the foundation for digital justice at the federal procedural level. However, its usage was rather scarce given that the non-compulsory nature of digital procedures allowed the favoring of manual procedure by traditional lawyers. Additionally, even though Amparo is a key constitutional control procedure, the normative provisions failed to quickly expand the scope of digital justice to include ordinary procedures.

b) The impact of the pandemic on digital justice. The COVID-19 pandemic increased the need for digital justice in Mexico substantially. As a preventative measure, the Federal Judiciary declared a work suspension on health and safety grounds in March 2020. However, the case backlog forced concrete actions. In June 2020, the Federal Judiciary extended the application of the electronic signature, electronic case files, and digital service of documents to all procedures within its jurisdiction ${ }^{10}$.

The administrative regulations issued also established the possibility of holding remote hearings, videoconference proceedings, and remote Court sessions. The Federal Judiciary Council itself justified the measure to deal with the pandemic while continuing procedures "on a large scale"11.

Before the pandemic, there was scarce regulation of the digital nature of Supreme Court proceedings, with the exception of Amparo. This was to change radically. The Supreme Court determined ${ }^{12}$ that all procedures may be filed and solved digitally through the usage of FIREL. Therefore, the Supreme Court extended the Amparo regulation to all procedures

9 Extensively analyzed in Yuritza Castillo, "Las notificaciones" in Juan González and Fernando Sosa and others (eds) Teoría y Práctica del Juicio de Amparo (Tribunal Superior de Justicia de la Ciudad de México 2020) 89-94. For a concrete analysis on the abovementioned digital record of the access, see 95-96.

10 See "Acuerdo General 12/2020, del Pleno del Consejo de la Judicatura Federal que regula la integración y trámite del expediente electrónico y el uso de videoconferencias en todos los asuntos de competencia de los órganos jurisdiccionales”.

11 ibid.

12 See "Acuerdo General número 13/2020, de trece de julio de dos mil veinte, del Pleno de la Suprema Corte de Justicia de la Nación, por el que se cancela el período de receso que conforme a lo previsto en el artículo 3o. de la Ley Orgánica del Poder Judicial de la Federación tendría lugar del dieciséis de julio al dos de agosto de dos mil veinte y, para este período, se prorroga la suspensión de plazos en los asuntos de su competencia y se habilitan los días que resulten necesarios para las actuaciones jurisdiccionales que se precisan”. 
such as actions of unconstitutionality ${ }^{13}$, constitutional controversies, competence conflicts, and other cases ${ }^{14}$.

The Supreme Court also advanced on implementing digital case files, thus permitting access to all parties and Supreme Court clerks ${ }^{15}$. The Court additionally authorized migrating procedures to remote Court sessions via the Zoom platform, thereby being instantly transmitted on YouTube and the Judicial Channel (Justicia TV) ${ }^{16}$.

c) The problematics of digital justice in Mexico. As noted, despite some traits of digital justice pertaining to constitutional control through Amparo prior to the pandemic, ordinary procedures in district courts lacked a digital procedure at the federal level. In addition, a substantial percentage of services of court documents and notices of entry were issued personally through actual clerks. The pandemic forced the Federal Council of the Judiciary and the Supreme Court to a rather fast and forced transition to digitalization.

Digital justice faces two current problems in Mexico. In the first case, while the measures taken by the Federal Judiciary represent a step towards digital justice, it should be considered that, due to their reactive nature, their true effectiveness remains the necessary subject of future assessment. A thorough evaluation process is required, which should be accompanied with technical training for a section of the law clerks ${ }^{17}$. For example, it has been common practice that Federal Courts, unfamiliar with the

13 See “Acuerdo General 8/2020, de veintiuno de mayo de dos mil veinte, del Pleno de la Suprema Corte de Justicia de la Nación, por el que se regula la integración de los expedientes impreso y electrónico en controversias constitucionales y acciones de inconstitucionalidad, así como el uso del sistema electrónico de este Alto Tribunal para la promoción, trámite, consulta, resolución y notificaciones por vía electrónica en los expedientes respectivos”.

14 See "Acuerdo General 9/2020, de veintiséis de mayo de dos mil veinte, del Pleno de la Suprema Corte de Justicia de la Nación, por el que se regula la integración de los expedientes impreso y electrónico de los asuntos de la competencia de este Alto Tribunal, salvo las controversias constitucionales y acciones de inconstitucionalidad, así como el uso del sistema electrónico de la Suprema Corte de Justicia de la Nación para la promoción, trámite, consulta, resolución y notificaciones por vía electrónica en los expedientes respectivos”.

15 ibid.

16 See "Acuerdo General 5/2020 de trece de abril de dos mil veinte, del Pleno de la Suprema Corte de Justicia de la Nación, por el que se regula la celebración de las sesiones de la Salas de este Alto Tribunal a distancia, mediante el uso de herramientas informáticas".

17 México Evalúa, Guía de Buenas Prácticas en el uso de nuevas tecnologías para la impartición de justicia ( $1^{\text {st }}$ edn Tinker Foundation 2020) 43. 
digital procedure, render interpretations of the law or the administrative regulations that hinder the procedure's effectiveness or require the involved parties to appear unnecessarily in Court physically. Furthermore, the current normative provisions are still largely based on employing technological tools to adapt the current procedures to the digital sphere instead of creating procedural designs to operate online fully ${ }^{18}$.

In the second case, there is a disparity between the Federal Judiciary and the local judiciaries. In 2021 only 24 of the 32 local judiciaries held electronic case files, while only 18 allowed electronic filing and service of documents ${ }^{19}$. Within these statistics the levels of development also vary notably in every State. It can definitively be argued that the Federal Judiciary has been more effective in implementing digital justice than its local counterparts.

\section{The Constitutionalization of Digital Justice: A Future Fundament Right or a Characterization of Justice in Mexico?}

The abovementioned scenario illustrates that Mexico started proactive efforts towards the digitalization of judicial proceedings in 2013. Nonetheless, the 2020 Pandemic produced an immense number of technical challenges to the Justice system and particularly to the Courts. After a couple of months, the initial absolute suspension was quickly discarded as a potential solution after the "new normality" showed that the impact of the Pandemic would be felt in the years to come. The Federal Public Administration and governmental bodies centered their efforts on remote working and informatics as the only means to proceed with the otherwise suspended physical activities. We have analyzed that the Federal Judiciary also undertook similar efforts. The Federal Judiciary was fortunate enough to have a base from which to build a progressive digitalization. Having the normative framework of the 2013 Amparo Act and a (rather minimal) four years' experience on its functioning, the path was eased. It is noteworthy that these measures were designed to mitigate the effects of the forced suspension and not to provide a reliable solution, which is undoubtedly

18 A similar observation by Arturo Ramos and Laura Márquez, Observatorio: Avances de Justicia Abierta en línea en México 2020 ( $1^{\text {st }}$ edn Escuela Libre de Derecho 2020) 74.

19 Laurence Pantin and Sandra Escamilla, 'La justicia digital en México: el saldo a un año del inicio de la Pandemia' (animalpolitico.com, 11 March 2021) <https://b it.ly/3sTibJi> accessed 27 April 2021. 
required. Such a solution may have come in the shape of a constitutional amendment.

In July 2020, Senator Ricardo Monreal (a member of "MORENA", the Parliamentary majority) sponsored a constitutional amendment to article 17 of the Constitution ${ }^{20}$, considering digital justice as a component of the right to access justice itself. Three months later, Senators Zepeda and Galvez (from the "PAN" party) sponsored their own proposal in similar terms ${ }^{21}$.

Article 17 of the Mexican Constitution provides a set of rights concerning access to justice (the right to free access to courts, the right to an anti-formalist nature of court proceedings, class actions as collective rights, the right to alternative dispute solution mechanisms, et cetera ${ }^{22}$ ). Constitutionally in Mexico, therefore, access to justice is characterized as free of charge, impartial, complete, fast, and expeditious (ensuring rulings are rendered within a reasonable time). The amendment would imply a further adjective to justice: "digital". Can digital justice become a fundamental right? Can justice itself be digital or not be deemed so?

a) Reasons for the amendments. The explanatory memorandum for Monreal's amendment explored the correlation between access to the internet and access to justice. The proposal dwells on the Joint Declaration on Freedom of Expression and the Internet ${ }^{23}$, the Mexican legal framework pertaining to access to the internet, and the right to access justice.

20 Ricardo Monreal, 'Iniciativa con Proyecto de Decreto por el que se reforma el artículo 17 de la Constitución Política de los Estados Unidos Mexicanos, en materia de digitalización de procesos judiciales' $<$ https://bit.ly/31ZgRth $>$ accessed 9 April 2021). See also the official website of the Senate concerning the parliamentary procedure's data of the proposed amendment: $<$ https://bit.ly/3dPRpMs $>$ accessed 9 April 2021.

21 Damián Zepeda and Xóchitl Gálvez, "Iniciativa con Proyecto de Decreto por el que se adiciona un párrafo cuarto al artículo 17 de la Constitución Política de los Estados Unidos Mexicanos en materia de Justicia Digital" < https://bit.ly/327x5Ra> accessed 10 April 2021). See also the official website of the Senate concerning the parliamentary procedure's data of the proposed amendment: $<$ https://bit.ly/3wQG V7U> accessed 10 April 2021.

22 A reference is Fernando Pérez, 'Artículo 17. Párrafo segundo' in José Ramón Cossío (ed) Constitución Política de los Estados Unidos Mexicanos Comentada” (Tirant lo Blanch 2017) 378-389.

23 See Joint Declaration on Freedom of Expression and the Internet by the United Nations (UN) Special Rapporteur on Freedom of Opinion and Expression, the Organization for Security and Co-operation in Europe (OSCE) Representative on Freedom of the Media, the Organization of American States (OAS) Special Rapporteur on Freedom of Expression and the African Commission on Human 
Moreover, the amendment analyzes several mechanisms in Europe, Asia, and the American continent concerning artificial intelligence and e-justice. Regarding the national framework, the initiative discusses the RR 1554/2019, in which the Supreme Court dismissed a claim pertaining to the need to provide digital justice in all judicial procedures. ${ }^{24}$ After providing a comprehensive analysis of the legal framework concerning digital procedures at the federal level, the amendment proposal stated the need to implement such mechanisms at a general level given the challenges presented by the Pandemic.

The Zepeda-Galvezes amendment dwells on the benefits that digital justice may provide in terms of quality and efficiency. The amendment analyzed the works of "Transparencia Mexicana" and "Tojil" which concluded $^{25}$ that after 100 days from the outbreak of the Pandemic, while the Mexican Federal Judiciary allowed full online procedures, only 16 of the 32 local judiciaries allowed a proper digital procedure. Zepeda's proposal also analyzed some of the examples in comparative law regarding digital justice, such as H@bilus (Portugal), NGCS (Israel) or XHIBIT (England), EFS (Singapur), et cetera.

b) Relevant changes. Monreal's amendment proposed introducing a progressive system to provide online justice, establishing virtual Courts through information and communication technology. It also stated that such regulations should comprise establishing full online procedures, regulating electronic case files and electronic signatures, and specify an elective or non-compulsory nature of online justice to the parties considering a progressive increase in internet access. Monreal's amendment proposed to force Federal and State Congresses to issue such legislation within 180 days of issuing the amendment.

and Peoples' Rights (ACHPR) Special Rapporteur on Freedom of Expression and Access to Information (adopted 1 June 2011).

24 Recurso de Reclamación 1554/2019 (04/09/2019), First Chamber of the Supreme Court. The Court dismissed the claim (pertaining to the admissibility of a "recurso de revision”). In its dissenting opinion, Justice González Alcántara stated that even though the Code did not foresee the digitalization of the procedure in commerce disputes, the Court should have analyzed if digital justice was a part of the access to justice itself and whether the omission of providing digital justice in certain procedures was rational or not. The amendment's proposal strongly highlights Justice González Alcántara's position.

25 See: Transparencia Mexicana, ‘Cómo será la justicia digital en la Nueva Era: Episodio 2' (www.tm.org.mx, 17 June 2020) <https://bit.ly/3sl4UsG> accessed 10 April 2021. 
In turn, Zepeda's amendment regulated in greater detail the inclusion of concepts such as digital files, videoconferences concerning hearings, and creating a general electronic filing system pertaining to filing and serving court documents. Therefore, both amendments' proposals seemed to draw inspiration from comparative experiences and recognized the need to force the states to implement digital justice to the same degree as the Federal Judiciary. As expected, the pandemic emergency played a notable role in both proposals.

c) From Senatorial approval to the road ahead: Feasibility of the amendment. The Joint Senatorial Legislative Committees of "Constitutional Amendments" and "Legislative Studies" after having studied both amendment proposals, issued a favorable opinion introducing certain changes $^{26}$, and moved it forward for consideration by the full Chamber. The Senate approved the amendment by a solid 97 votes (out of 120 senators) on March 2021. The approved amendment includes a transitory regime that binds the General and Local Congress to issue secondary legislation within 180 days and forces local and Federal Parliaments to foresee a budgetary reserve to implement digital justice "progressively."

After the Senate's approval, the constitutional amendment would need to pass a $2 / 3$ qualified vote in the Chamber of Deputies and attain a simple majority of the State Parliaments (17/32). Is it a possible road?

The introduction of such a fundamental right at the constitutional level may seem complicated though there are at least two factors, which may decisively tilt the scales. In first place, the recent discussion in Mexico towards digital environments prompted by the Constitution's recognition of a right to internet and telecommunications in the Constitution, and in second place, the political nature of the Mexican constitutional amendment procedure.

Regarding the first factor, article 6 of the Constitution was amended in 2013 to establish a right to access broadcasting and telecommunication services "including broadband and internet". Not only was the right recognized, but also the State was bound to establishing proper competence

26 The amendment approved by the Senate is: "Article 17 (...) To guarantee access of justice in a fast, timely and inclusive way, the Federal and local Judiciary Power, the Federal and local Administrative Courts, Agrarian Courts, Labor Courts, local and Federal Electoral Courts shall implement digital justice systems employing Information and communications technology to provide full digital trials and electronic access and serving of documents in the terms prescribed by the law. A Law shall establish the type of hearings that must be physical to ensure an adequate administration of justice”. 
conditions in order to provide the services ${ }^{27}$. Both amendment proposals dwelled upon the right to access the internet and therefore deemed that a natural relationship between such a right and access to justice must recognize digital justice as an essential constitutional component of all court procedures.

In relation to the second factor, Mexico's Constitution has often been described as formally rigid (in Brycean terms ${ }^{28}$ ) but materially flexible ${ }^{29}$. Prof. Valadés famously stated that constitutional amendments seemed to be in Mexico "a living testimony of what the country has deemed the most relevant content of a temporary political program ${ }^{30}$."

The Pandemic will certainly be one of the most significant events during López Obrador's Presidency and MORENA's parliamentary majority: an amendment certainly would be expected under the political conception of the Constitution by the political actors. Senator Monreal belongs to the "MORENA" party, the majoritarian party in both the Chamber of Deputies and the Senate. After the 2018 election, MORENA has performed exceptionally well with passing amendments consolidating its main policies, and this one might not be the exception.

Morena holds a solid 51.4\% majority in the Chamber of Deputies. In turn, Senators Zepeda and Gálvez belong to the "Partido Acción Nacional" (PAN) party, the first minority in the Chamber of Deputies, holding a $15.6 \%$ and therefore very few votes are practically required to pass the amendment in the lower Chamber. That is, both parties combined (67\% of the Chamber) hold more than the $2 / 3$ qualified majority required to approve the amendment. It is worth noting that the Federal Entities generally approve all constitutional amendments passed by Congress ${ }^{31}$. Therefore, in terms of Mexican reality, approving the amendment in the Chamber of

27 The transitory regime (Article 14) even stated that the Federal Executive shall guarantee broadband access to internet in every building and entity of the Federal Public Administration.

28 James Bryce, Flexible and Rigid Constitutions ( $1^{\text {st }}$ edn Oxford University Press 1905) 7.

29 Inter alia, Mauro Arturo Rivera, 'Understanding Constitutional Amendments in Mexico: Perpetuum Mobile Constitution’ (2017) 2 Mexican Law Review 3, 6. The accelerated amendment rhythm of the Mexican Constitution has been a source of academic fascination.

30 Diego Valadés, La Constitución reformada (1 $1^{\text {st }}$ edn IIJ-UNAM 1987) 12.

31 Mauro Arturo Rivera, 'De Directores y Orquestas: Análisis comparado de la posición institucional del Consejo de la Judicatura Federal en México’ (2020) 159 Boletín Mexicano de Derecho Comparado 1139, 1143. 
Deputies would practically ensure that the Constitution would be definitively amended in 2021.

\section{More Challenges than Certainties: A Provisional Conclusion}

Our analysis has shown that the first solid steps towards digital justice in Mexico were taken in 2013 only concerning Amparo. However, the COVID-19 Pandemic forced the Federal Judiciary to rely on that legal framework to provide online justice in other procedures. The transition was forced and unplanned, a tough necessity given the pressing circumstances as shown by the substantial differences visible between the Federal Judiciary and the local Judiciaries of the States.

The Senate's approval of the Monreal/Zepeda\&Galvez amendment to article 17 of the Constitution proved that the legislative branch learned from the Federal Judiciary measures and tried to further expand on the remedial actions taken. The amendment would imply either creating a fundamental right to digital justice or, at the very least, constitutionally stating that "digital" is an intrinsically necessary characterization of justice.

The amendment procedure in Mexico and the strong support attained by the Senate's proposal render such an amendment feasible to be approved in 2021. Mexico would become one of the very first countries to guarantee digital justice constitutionally. The scenario certainly might look promising, however, we need to bear in mind that any further recognition of rights does not necessarily expand the rights per se. Of course, constitutionalization in itself would imply the possibility of submitting to judicial review cases in which digital justice is not provided ${ }^{32}$ or imposing budgetary obligations to the Federation and the States to guarantee full online procedures. However, constitutionalizing digital justice will not create this if not followed by an intensive intervention at both the federal and state levels.

At the federal level, it would imply creating an enduring legal framework and not relying on the provisionary regulations issued by the Supreme Court and the Federal Council of the Judiciary. A comprehensive approach might require formal amendments to procedural regulations. At

32 The Mexican Supreme Court holds a firm doctrine allowing to appeal legislative omissions through amparo. For example AR $1359 / 2019$ by the First Chamber (also known as the "Artículo 19" case) or AR 805/2018 (hate speech case), by the First Chamber. 
the state level, the struggle widens. While some states are at an advanced level, others will require intensive intervention to develop functional models.

Introducing a constitutional provision guaranteeing digital justice would probably position Mexico as a pioneering country in pure normative terms: nonetheless, a tough road will still lie ahead. 